\title{
Qualitative research and knowledge transfer - from project to decision-making?
}

\author{
Cristina Lavareda Baixinho' \\ ORCID: 0000-0001-7417-1732 \\ Helena Presado' \\ ORCID: 0000-0002-6852-7875 \\ Óscar Ferreira' \\ ORCID: 0000-0002-1703-347X \\ António Pedro Costa" \\ ORCID: 0000-0002-4644-5879
}

'Escola Superior de Enfermagem de Lisboa. Lisbon, Portugal. "Ludomedia/webQDA e Centro de Investigação de Didática e Tecnologia na Formação de Formadores Research (CIDTFF), Universidade de Aveiro. Aveiro, Portugal.

How to cite this article: Baixinho CL, Presado H, Ferreira O, Costa AP. Qualitative research and knowledge transfer - from project to decisionmaking?. Rev Bras Enferm [Internet]. 2019;72(1):1-2. DOI: http://dx.doi.org/10.1590/0034-7167.20197201
The proliferation of scientific studies and the dissemination of their results in health have undoubtedly contributed to improving care, increasing average life expectancy, reducing mortality, morbidity and complications associated with chronic diseases, among others.

Associated with these gains, new challenges for the clinic and the academy have arisen. Clinicians are driven to constant updating and selftraining to keep abreast of rapid scientific and technological advances. On the other hand, health units are also encouraged to promote rapid, deep and structured changes in the organization of care and in the planning and management of resources, in the light of cost control, with a clear focus on developing clinical skills, but also of leadership skills, adaptation, management, problem-solving, innovation and creativity. In academia, the challenge of disseminating and disseminating scientific findings more effectively, promoting and streamlining their use in the clinic, while fostering evidence-based decision-making ${ }^{(1)}$.

The traditional models of Evidence-Based Practice have long been questioned, using linear and unidirectional models, which passively'pass on' the information of researchers to users and consumers in relation to their effectiveness ${ }^{(1-2)}$. Therefore, academics need to unveil solutions so that, from the planning to the implementation of the research project, the transfer of the findings to the clinic $^{(1)}$.

The definition of the object of study with the clear identification of the phenomena of interest, the methods and techniques to investigate them remains a present challenge for any researcher nowadays, but without doubt, that the future brings the emergence of knowledge production that can be transferred to the clinic, with the valorization and empowerment of clinical praxis ${ }^{(1)}$.

In order to (re)think the transfer of knowledge to the clinic, it is necessary to question the ways of investigating and the way clinicians understand the investigation, not only the results, but the whole process, since a broad understanding of how it was validity, adequacy and objectivity of the findings allows an appreciation of its quality ${ }^{(1)}$. For this reason, from the conception to the dissemination of the results, the researcher must be able to structure the analytical process in order to make understandable what the findings reveal, so as to enable the professional, probably less skilled in the art of investigation, to understand the usefulness and impact they can have on improving care delivery ${ }^{(1)}$.

The epistemological break with the traditional view of the production of knowledge obliges the researcher to a better understanding of the impact of his study in the clinic, through the collaborative work and in network, with the diverse institutional actors.

A new working methodology based on felt needs and in collaboration with contexts can promote a qualitative transformation of practice with individualization of care; and a direct benefit to citizens' health ${ }^{(1)}$. Thus, it is necessary to move to a new paradigm and modify the networks of communication and collaboration between researchers and professionals, promoting reflection on practices, "ways of doing" and the consequences of the activity, using research-based knowledge $\mathrm{e}^{(1-2)}$, for decision-making. 
The articles in this issue of REBEn illustrate different steps in the process of transferring knowledge to the clinic. From the qualitative research, the authors show how the correct application of methods and techniques in this field can effectively contribute to the improvement of the understanding of the phenomena experienced by the person in different health/disease transitions, quality and organization of care.

\section{REFERENCES}

1. Baixinho $C L$, Ferreira Ó, Marques FM, Presado MH, Cardoso M, Sousa AD. Investigação Qualitativa e transferência do conhecimento para a clínica. In: Brandão C, Carvalho JL, Ribeiro J, Costa AP. A prática na Investigação Qualitativa: exemplos de estudos (vol.2). Oliveira de Azeméis: Ludomédia, 2018; p.179-208.

2. Baumbusch JL, Kirkham SR, Khan KB, McDonald H, Semeniuk P, Tan E, Anderson JM. Pursuing Common Agendas: A Collaborative Model for Knowledge Translation between Research and Practice in Clínical Settings. Res Nurs Health. 2008;31(2):130 40. doi: 10.1002/nur.20242 